\title{
Technology Prospecting on Enzymes for the Pulp and Paper Industry
}

\author{
Braz J. Demuner', Nei Pereira Junior ${ }^{2}$,Adelaide M.S.Antunes ${ }^{3}$
}

\begin{abstract}
The use of enzymes in the pulp and paper industry was introduced in the 1986. However, their use has been relatively minor. This prospective study aims at enhancing the understanding of the most important advances regarding the use of enzymes in this industry and to identify the future trends of this technology. Information gathered from the Web of Science shows a growing number of papers published on this topic indicating an increased interest in this issue. A study on patents also displayed a high number documents related to this technology. Cellulase, xylanase, laccase and lipase are the most important enzymes that can be used in the pulp and paper processes. Furthermore, the key objectives of enzymes development have been in the bleaching boosting with xylanases and fiber modification with cellulases. The current and future trends on the development of enzymes are focused on increasing their thermostability and their alkalinity strength.
\end{abstract}

Keywords: Enzymes innovation; cellulase; xylanase; laccase; lipase; pulp; paper; enzyme thermostability; fiber modification.

\footnotetext{
'Fibria Celulose. Rod.Aracruz Barra do Riacho, km25, s/n. ZIP CODE: 29197-900.Aracruz. ES. Brazil.Tel.+552732702397. Email:bd@fibria.com.br. 1,2,3 Chemical School - Federal University of Rio de Janeiro (UFRJ). Graduate Program on Technology of Biochemical and Chemical Processes. Av. Horácio Macedo, 2030. Technology Center, E building. ZIP CODE: 2 I94 I-909. Tel. +552 I25627644. Email: nei@eq.ufri.br. and +552 I 25627426. Email: adelaide@eq.ufri.br.

${ }^{3}$ INPI - Brazilian National Institute of Industrial Property. Praça Mauá, 7 - Centro. Rio de Janeiro, RJ - CEP 2008I-240. Tel. +552 I 303732 I I. Email: academia@inpi.gov.br.
} 


\section{Introduction}

The competitiveness of a company is related to its capacity to search and implement new and innovative opportunities so as to overcome technical barriers. One base level indicator for enterprise leadership is the capacity of a company to manage key growth elements such as science, technology and innovation (Viotti, 2003). Therefore, companies tend to incorporate adequate systems for monitoring and searching change signals and new business trends in the market.

The ability to properly analyze important technological and innovative indicators is essential for increasing business performance. Such analyses also influence the necessary advancements in production processes, communications and the uses of science, technology and innovation. These analyses should influence the definition, review and implementation of competitive strategies within companies (Viotti, 200I). In this context, the technological management system is a powerful tool that was developed as a result of the search for and analysis of relevant information, such as patent information, (Antunes et al., 2008). It is well known that the patent document contains relevant technological information (Araújo, 1984; Cabral, 1999). These authors justify the importance of the documents because patents contain the most recent technological information available by providing descriptions of the projected inventions. In fact, patent documents contain $71 \%$ of all the published information available on technology.

The objective of this study is to identify the most relevant advances and future trends for the use of enzymes in the pulp and paper industry. It is important to note that the pulp and paper sector plays a critical role in the world economy as it continues to experience significant growth in Brazil. Although history denotes that the first industrial trials with enzymes were carried out in 1986 (Viikari et al., 1986), the pulp and paper industry still presents only marginal uses of enzymes in their production processes. On the other hand, many literature reviews on the industrial use of enzymes (Bajpai, 1999; Beg, 200I; Viikari, et al. 1994; Kirk and Jeffries, 1996; Bajpai and Bajpai, 1992; Suurnakki et al., 1997; Keneraly and Jeffries, 2003; Sukumaran et al., 2005; Moreira and Filho, 2008; Khandeparker and Numan, 2008; Ahmed et al., 2009; Sanghi et al., 2009; Carvalho et al., 2009; Sashi et al., 2009; Bajpai, 2010; Canas and Camarero, 2010; Sanchez and Demain, 201I) suggest that recent significant developments and enhancements of enzyme characteristics have been achieved. These aspects justify the importance of this study to gather new relevant information about the enzyme technology for the pulp and paper industry.

\section{Procedure}

Seekingtoidentify the extent of the researchand the number of published documents on the use of enzymes in pulp and paper processing, we have searched the Web of Science database through the CAPES portal from 1945 to July 2010.

Patents were searched in the Derwent Innovation IndexSM database, from 1963 to July 2010, to find the most current information available on the use of enzymes in the pulp and paper industry. This database includes patents filed in different countries. The International Patent Classification (IPC) code for microorganism or enzymes: compositions thereof is $\mathrm{CI} 2 \mathrm{~N}$. Additionally, there many classes and sub-classes which make this code $\mathrm{CI} 2 \mathrm{~N}$ wider, but since it was not the case here to go deeper on those aspects, a useful trunked strategy was used, applying the "**" in the $\mathrm{CI} 2 \mathrm{~N}$. Thus, the searching was done using the $\mathrm{IP}=(\mathrm{CI} 2 \mathrm{~N} *)$ associated with the TS=(enzyme and pulp or paper), where IP corresponds to the IPC, and TS is related to the topic, which means that the keywords 'enzyme and pulp or paper' can be located in the title and or in the abstract of each patent. This search resulted in the generation of a databank of 1048 documents. The extraction of basic information from these documents, such as priority, country of priority, patent owners, year of publication, and major enzymes described, was performed using VantagePoint $®$ software, Version 5.0, 2007, according the user's guide (Vantage Point, 2007). Finally, these documents were read to separate those ones that were specifically related to the pulp and paper industry.

It was concluded that 602 of the original 1048 documents were strictly related to the use of enzymes in the processing of pulp and paper. Thus, the analysis presented in this paper is related to the information obtained from those 602 patent documents. The most relevant information included, but was not limited to, owners of potential innovations, potential innovations presented by private companies or by universities/public 
institutions, countries of priority, applications in pulp or paper, major objectives of the enzymes developments and the key biotechnological techniques used in the designs of any applied enzymes. Regarding the right of priority it is important to mention that it is as defined by the "Paris Conventional Priority Right". Patent priority relates to the issue of who is entitled to a patent when two different inventors create the same invention and seek patents on those inventions, but they filed the patent in different time. The issue of who gets the patent is the issue of "patent priority." In the United States, the issue of patent priority is determined by the so-called "first to invent" rule. Most foreign countries, however, use an alternative rule called the "first to file" rule.

In addition, a new search was performed using the USPTO database to find the number (evolution) of filed documents specific for the key phrase "enzymes and pulp or paper" found in each patent abstract, from 1790 to July2010. Differently from the Derwent database, the USPTO contains patents filed in the U.S. only. This search was executed to confirm the level of interest for R\&D on enzyme use in the processing of pulp and paper, since it was clear that the U.S. lead the number of priority of patent on enzymes for the pulp and paper industry.

\section{Results and Discussion}

\section{Evolution of the number of published documents on enzymes}

A consistent evolution of the number of published documents on enzyme use in the pulp and paper industry is shown in figure I. Although the searching was required from 1945 to July 2010, it shows that the publications on enzymes for pulp and paper applications have started in 1976. Taking the data from 2006 and 2010 in comparison to the period from 2001 to 2005 there was an increase of $48 \%$ in published material in the Web of Science. This trend confirms that this issue continues to draw interest in the scientific community.

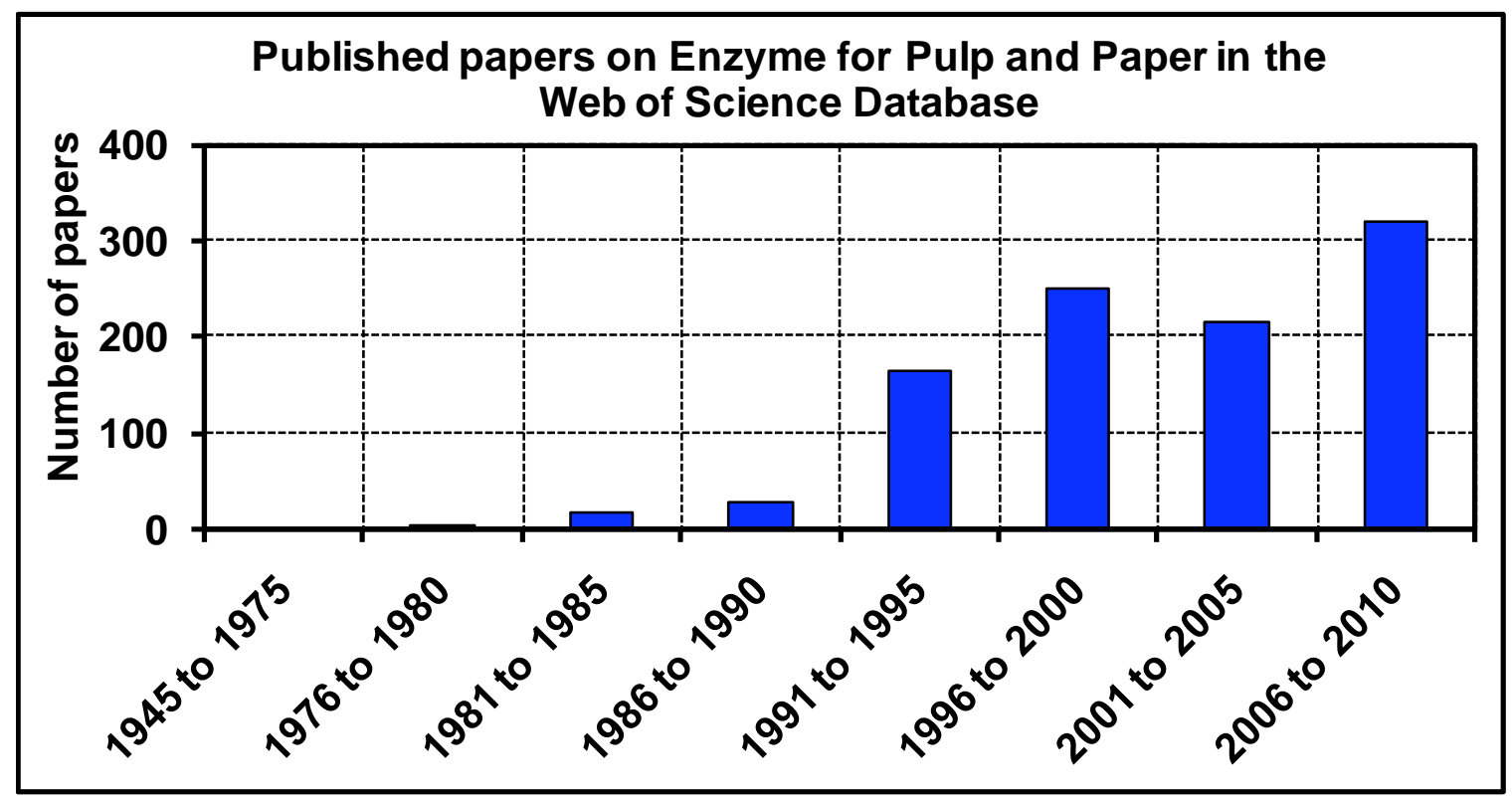

Figure I. Number of published documents on enzymes for the pulp and paper industry in the Web of Science database, from 1945 to July 2010. 
Based on the Web of Science database, it was determined the most relevant areas of interest on enzyme design: technology \& applied microbiology with $30,7 \%$ publications; chemistry with $26,5 \%$ publications; material science with $25,8 \%$ publications, food science and technology with $9 \%$ publications and, finally, biochemistry \& molecular biology with $7,8 \%$ publications. This information provides a foundation to guide and focus the research, the core competence development, and the R\&D investments on enzyme use in the pulp and paper industry.

\section{Patenting evolution of enzymes for pulp and paper industry application}

It is important to note the heavy increase in the innovative potential (technological intensity) on enzymes for the pulp and paper industry. As a relatively recent development (laboratory R\&D studies started in 1976), the topic has continued to gain interest since that time. The data from the USPTO include the number of filed documents from 200I to 2010 (figure 2a) and serve as key information for our research. The average number of filed documents from 2001 to July 2010 was 33 per year. It essentially confirmed the results of the information gathered from the 602 documents extracted using the Derwent Innovation database (figure $2 \mathrm{~b}$ ), with showed an average of 30 patents per year from 1993 to 2008 (a wider time length than that used in the USPTO).

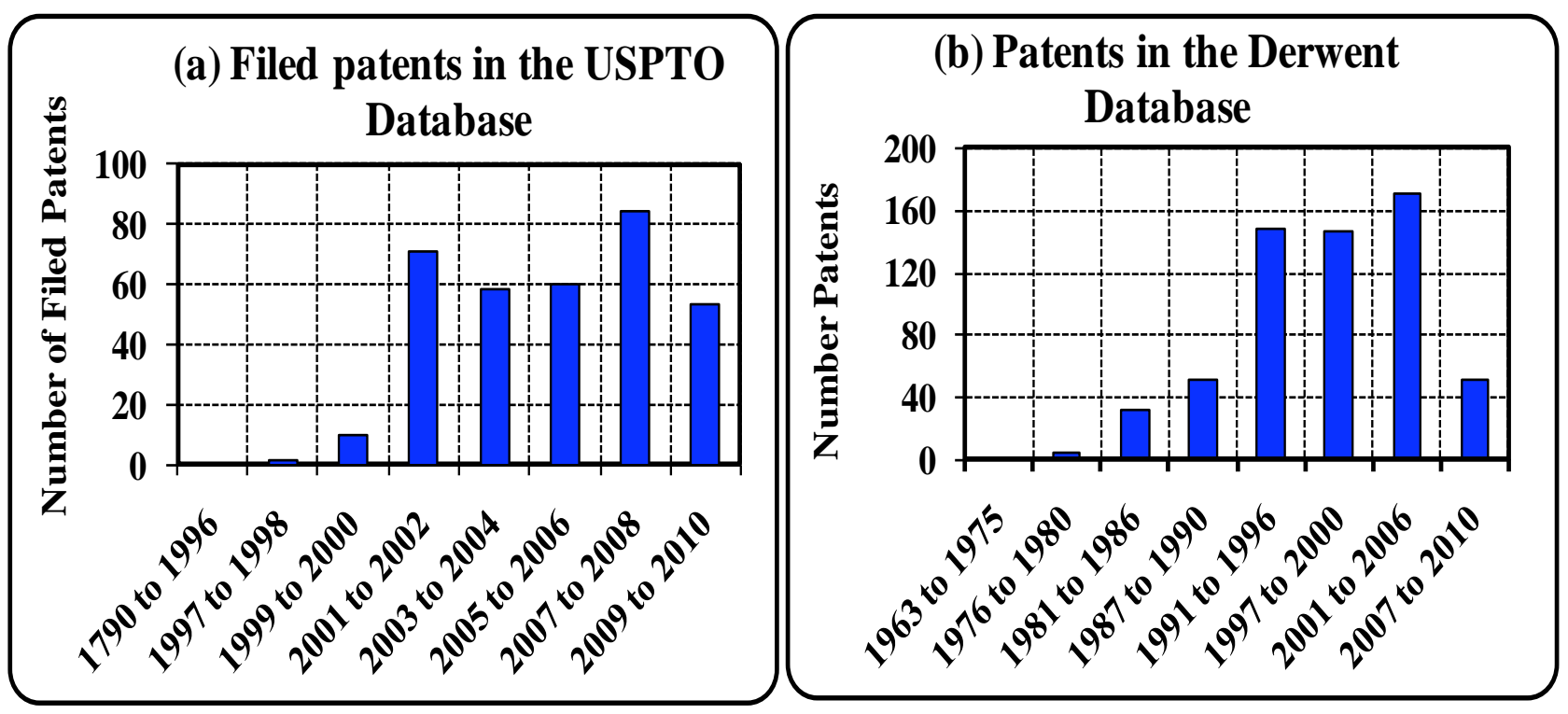

Figure 2. Number of patents on enzymes for P\&P (a) in the USPTO, from 1790 to July 2010, and (b) in the Derwent database, from 1963 to July 2010.

\section{Major assignees of patents}

First, it is important to underscore that only one company in the pulp and paper industry, Oji Paper (figure 3), is the assignee of a numerous (19) patents. This indicates a strong interest by this Japanese company to invest and develop its own technology.
Another critical observation is that the development of enzymes for the pulp and paper sector is heavily concentrated in only a few biotech enterprises (figure 3a) dominated by Novonordisk and Novozymes. Data presented by Linton et al. (2009) and data from the Novozymes 2009 Annual Report (Novozymes, 2010) demonstrate that this company has been consistently increasing the investments in R\&D and increasing its sales in enzymes for the pulp and paper industry. 


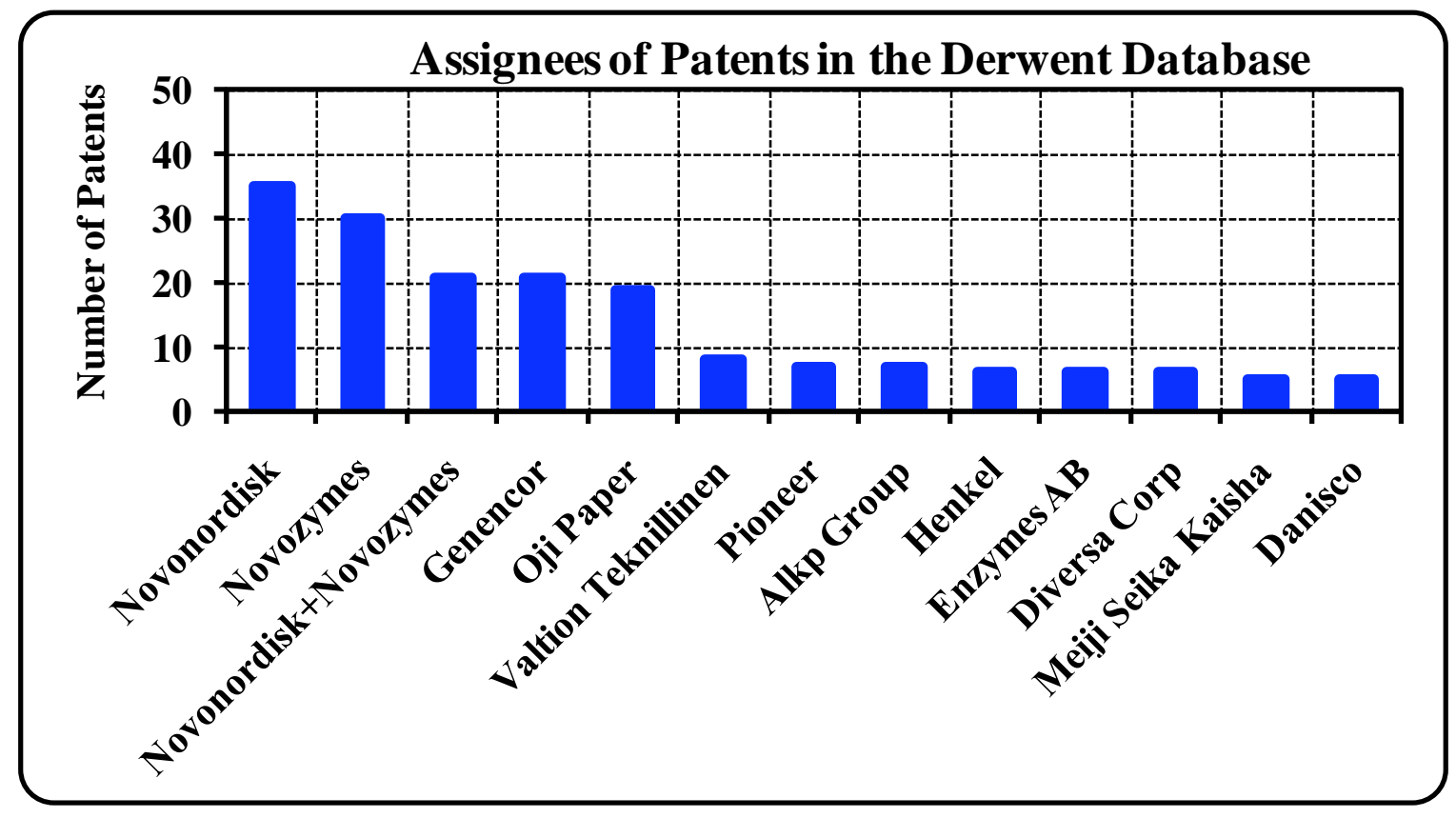

Figure 3. Major companies assignees of patents, in the Derwent database from 1963 to July 2010.

\section{Private versus public assignees of patents}

Figure 4a shows that the number of patents to private companies is five times higher than public ones. This appears to confirm that the R\&D efforts on enzyme use in the industrial sector have been primarily carried out by biotechnology companies.

\section{Countries assignees of patents on enzymes for the P\&P industry}

Figure $4 \mathrm{~b}$ shows that the U.S., with 209 documents, leads the field in the number of granted patents on enzymes for this industrial sector. This statistic fits as the U.S. is both the world's major pulp producer as well as the world's largest consumer. Another relevant factor is that many of the biotech companies that are leading the field in enzyme development are currently based in the United State. Japan is a distant second with 59 patents, followed by Denmark, China and various European countries.

Innovative potential obtained from the patents

A comprehensive analysis of the 602 patents was carried out to understand some specific and relevant aspects of the innovative potential of enzyme for P\&P application. Some important predefined aspects were the type of enzyme, purpose of enzyme development, innovation focus, microorganisms used in the development, major objective of the innovation, and key biotechnology techniques applied. 


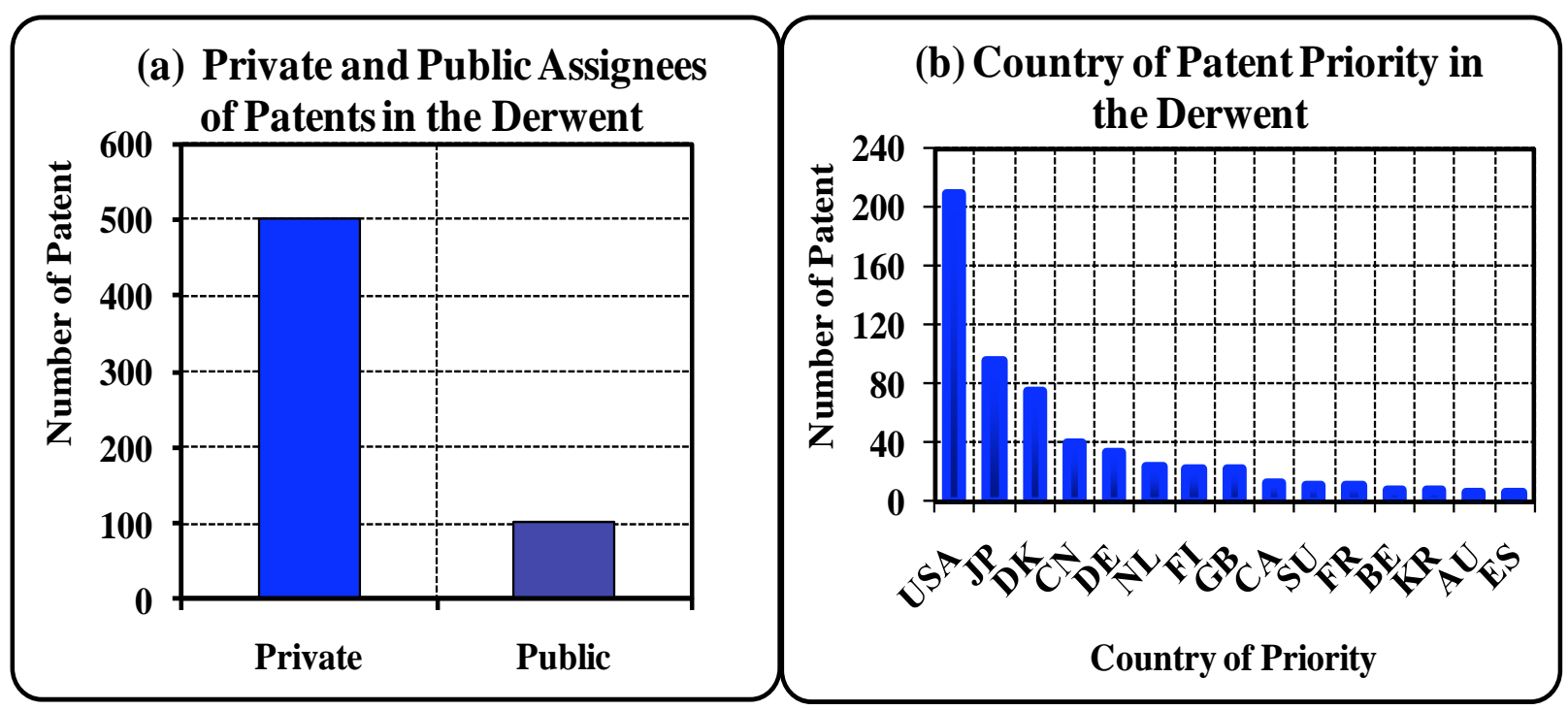

Figure 4. (a) Ratio between the number of patents of private versus public assignees. (b) Major countries of priority of patent on enzyme for pulp and paper in the Derwent database from 1963 to July 2010.

A search of key words to provide evidence of the presence of the above-listed key aspects was executed using VantagePoint $₫$ software. Cross correlations and the principal clusters were also obtained through this commercial available software - the VantagePoint. Figure 5a displays the different types of enzymes used in the pulp and paper industry. The most important are cellulase, $x y l a n a s e$, laccase and lipase. The information presented in figure $5 \mathrm{~b}$ indicates that cellulases and lipases are primarily applied in the processing of paper, whereas xylanase and laccase are more commonly found in the bleaching and delignification processes. In addition to that, figure 6 illustrates the most relevant objectives of enzyme applications in pulp and paper processes, which are: bleaching boosting, mostly obtained with xylanases, enhancement of pulp delignification, primary reached with laccases uses, fiber modification, a key cellulase target, and pitch control, possible only with the lipases application, among others with minor importance. On the other hand, is also clear that a great effort were applied in the development of these four enzymes in order to increase their thermostability (figure 6b). Moreover, this figure also shows that xylanase and cellulases were developed to turn them more alkali-tolerant.

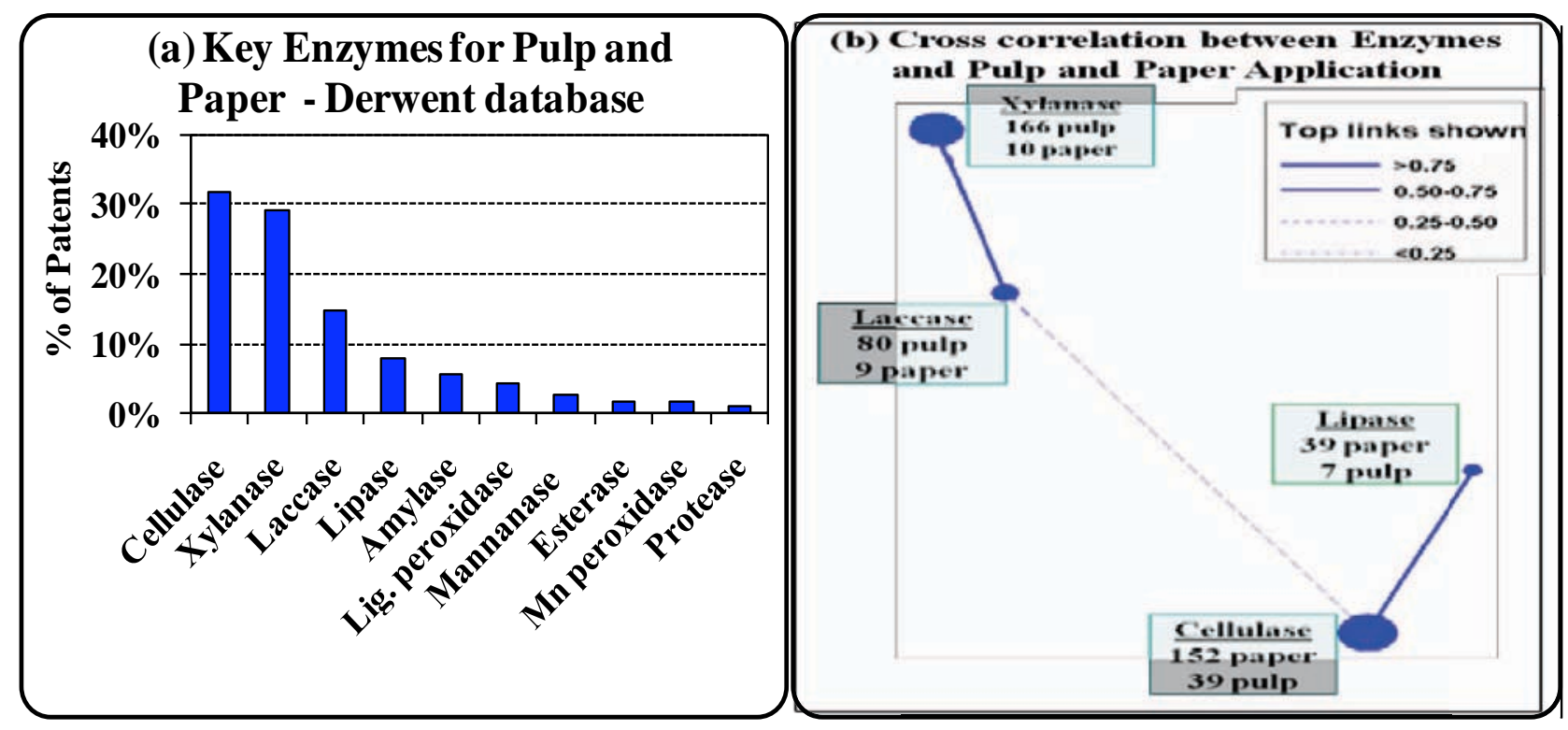

Figure 5. Key enzymes extracted in the patents from the Derwent database (from 1963 to July 2010) and their major applications in pulp and paper. 

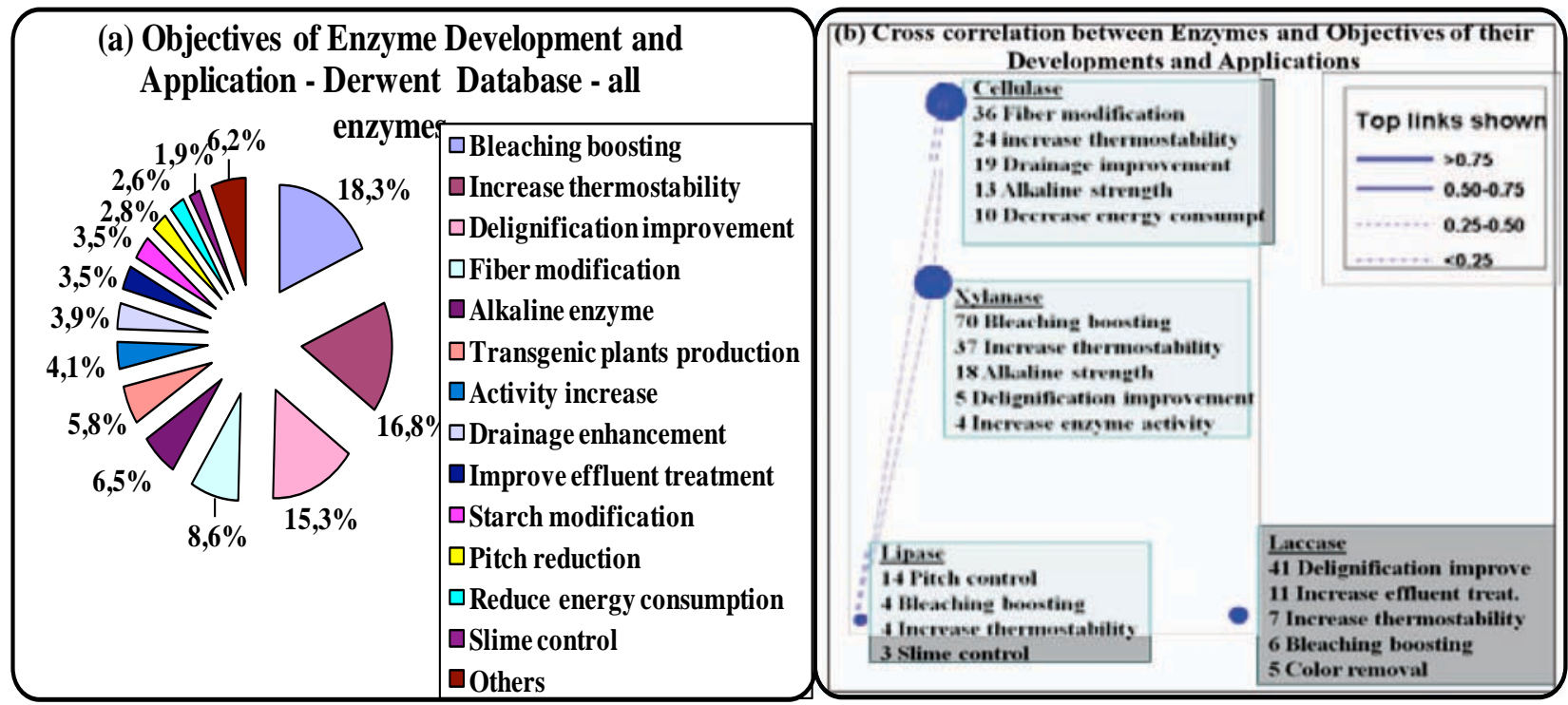

Figure 6. Major objectives of development and applications of enzymes, as extracted in the patents on enzyme for pulp and paper in the Derwent database from 1963 to July 2010.

This detailed study around the patent key information shows that all four enzymes: cellulase, xylanase, laccase and lipase have been designed through the use of modern biotechnology techniques, which are mostly encoding, recombinant DNA, mutagenesis and PCR (figure 7). This is in fully agreement with the fact that over $50 \%$ of the enzyme market is provided by recombinant enzymes (Sanchez \&
Demain, 20II). This also supports the recognition that large-scale production of xylanases was facilitated with the advent of genetic engineering (Ahmed et al., 2009; Sarveshni, 2007). And Kuhad and Singh, 2007 stated that the advent of recombinant DNA technology in the late 1970s further paved the way for developing technologies based on lignocellulolytic microbes and enzymes

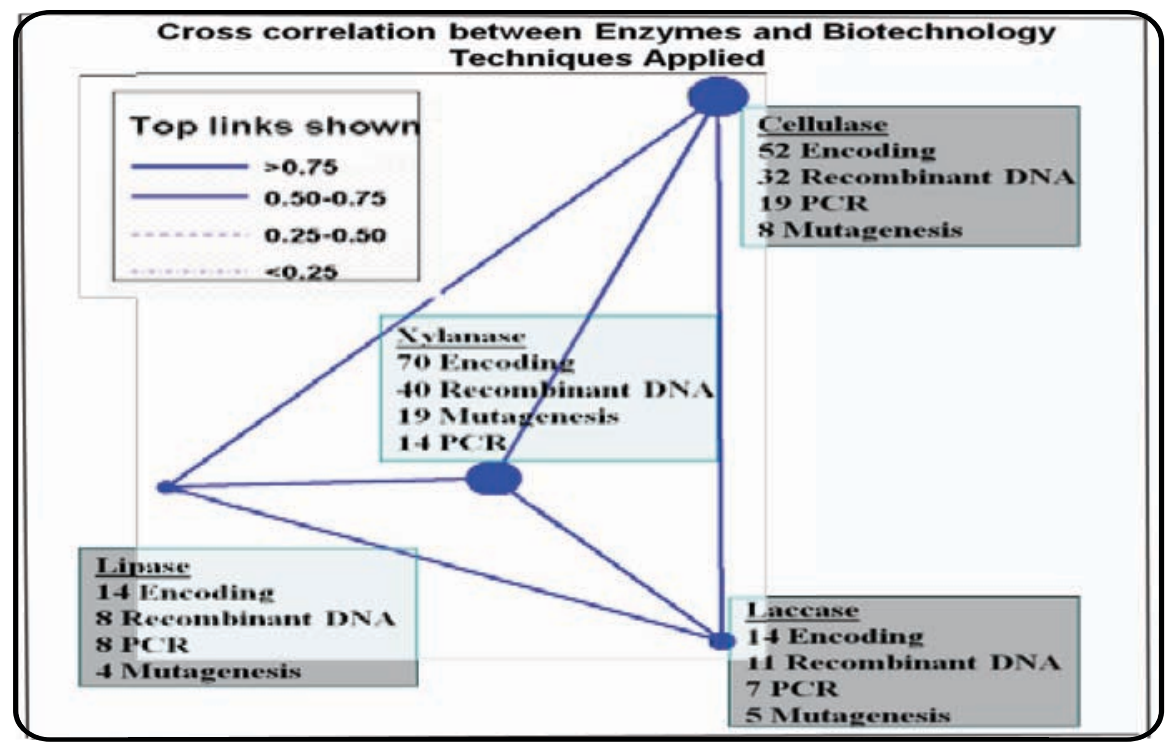

Figure 7. Key biotechnology techniques applied in the enzyme development - patents extracted in the Derwent database, from I963 to July 2010. 


\section{Enzyme Application in the Pulp and Paper Industry}

While many applications of enzymes in the pulp and paper industry are still in the research and development stage, some applications have found their way into the mills. Currently the most important application of enzymes is in the prebleaching. Xylanase prebleaching technology is now in use at several mills worldwide (Bajpai, 1999; Quinde, 1994; Leisola et al., 200I; Burgt et al., 2002; Keneraly and Jeffries, 2003, Paice 2005). Taking some examples, xylanase was used in $8 \%$ of Canada's bleached kraft pulp (830,000 tonnes) in 1994 (Tolan, 1995). It increased to over than 3.9 million tonnes of pulp in North America in 200I and then to 6 million tonnes in 2002 (Burgt et al., 2002). logen xylanases only have treated more than 10 million tonnes of pulp up to 2011 (logen, 20II). In 2002 there were 20 mills using xylanase in North America (Burgt et al., 2002). In Scandinavia there were 9 mills using xylanase in 1999 (Senior et al., 1999). More recently, there are also indications that some of the Eucalyptus pulp mills in Chile have been testing products of xylanase pretreatment of unbleached eucalyptus kraft pulp (Noah, 20II). In Brazil there is one pulp mill applying xylanase in continuous operation.

Nissen et al. (1992) pointed out that with the xylanases available commercially in 1992, a pH adjustment of the incoming pulp from $\mathrm{pH} 10-1 \mathrm{l}$ to $6-8$ is necessary for its optimal activity. From an industrial point of view, it is simple to adjust the $\mathrm{pH}$ but difficult and expensive to control temperature due to the cost of cooling. The ideal solution therefore would be to use enzymes with higher $\mathrm{pH}$ and temperature stability, which will make the large-scale operations more simple and cost effective. It is thus obvious that the focus of future developments will be on identifying xylanases with higher thermostability at high alkaline $\mathrm{pH}$, and developing process technologies for commercial-scale manufacture of such enzymes. Since that time many studies were carried out in order to produce xylanases for a better fit the temperature and $\mathrm{pH}$ of the pulping and paper processes. Research has been actively underway to identify and extract enzymes from "extremophilic" bacteria which live in hot springs (Tolan et. al.,1995). Tolan et. al. (1995) also described that enzymes promise to be more resilient to $\mathrm{pH}$ and temperature conditions, allowing for greater delignification capabilities. Van der Burgt (2002) pointed out that there are indications that most of the xylanase applied are engineered and they are more effective than before.
One result of the patent analysis showed that the enzyme thermostability was the major objective of the enzyme engineering (Figure 6b). And when the more recent literature was analyzed, it was confirmed that there still are many studies covering the designing, production and optimization of enzymes in order to turn them more thermostable and highly $\mathrm{pH}$-adaptable (Nagar et al., 2010; Azeri et al., 2010; Bai et al. 2010; Zhang et al., 2010; Kaur and Mahajan, 20II; Joshi and Khare, 20II; Mishra and Thakur, 20II).

\section{Conclusions}

There is a high global R\&D interest in the development and application of enzymes in the pulp and paper industry. This is demonstrated by the high number of published scientific papers and patents in this topic, which continued to increase every year since 1995.

Cellulases, xylanases, laccases and lipases are the most applicable enzymes in pulp and paper industry. While cellulases and lipases have been applied in the papermaking processes, xylanases and laccases have been primary used in the pulp production. Fiber modification and pitch control have been the key aims of cellulases and lipases applications, respectively. On the other hand, fiber delignification and pulp bleach boosting have been the most important objectives of laccases and xylanases application in pulp production.

The current and future most relevant perspectives on the development of enzymes for the pulp and paper application are concentrated on increasing their thermostability and their alkaline strength, which have been achieved through the use of some modern biotechnology techniques, such as recombinant DNA, mutagenesis, PCR and encoding. With the availability of engineered enzymes that can better fit the pulping and papermaking processes it is also expected to increase the number of full-scale implementation with enzymes. 


\section{Acknowledgments}

The authors express their gratitude to Flavia M.L.Mendes, from SIQUIM-UFRJ, and Daniel Hoefle (former SIQUIM), for their effort in the application of the VantagePoint ${ }^{\circledR}$ software. We are also grateful to Fibria Celulose S.A., who is supporting Braz during his DSc studies, at UFRJ. Thanks also to Paulo Pavan and Ergilio Claudio-da-Sivla Jr., who are managers of Fibria Celulose S.A., for their useful suggestions in the text of this paper.

\section{References}

AHMED, S. et al.. (2009). Molecular cloning of fungal xylanases: an overview. Applied Microbiology and Biotechnology, 84(I), 19-35.

ANTUNES, A.M.S. et al. (2008). Patenting \& Technology Prospecting in the Pharmaceutical Sector. SIQUIM, Interscience Ed. Rio de Janeiro, Brazil. 286p.

ARAÚJO, V.M.R.H. (2003). Use of the patent information in development countries. Information of Science I3(I), 53-56.

AZERI, C et al. (2010). Thermoactive cellulase-free xylanase production from alkalophilic Bacillus strains using various agro-residues and their potential in biobleaching of kraft pulp. Journal of Wood Chemistry and Technology, 30(I), 86-104.

BAI, Y.G. et al. (20I0). A new xylanase from thermoacidophilic Alicyclobacillus sp A4 with broad-range $\mathrm{pH}$ activity and $\mathrm{pH}$ stability. Journal of Industrial Microbiology \& Technology, 37(2), 187-194.

BAJPAI, P., and Bajpai, P.K. (1992). Bioleaching o kraft pulp. Process Biochemistry, 27(6),319-325.

BAJPAI, P. (1999). Biotechnol. Prog., (I5), I47-I57.

BAJPAI, P. (2010). "Review of enzyme use for recycling". BioResources, 5(2), I-I5.

BEG, Q.K. et al. (200I). Microbial xylanases and their industrial applications: a review. Applied Microbiology and Biotechnology, 56(3-4):326-338.

BURGT, T.V. et al. (2002). US kraft mills lead in xylanase implementation. In: Tappi pulping conference. San Diego, CA.
CABRAL, L.L. (1999). How to Access and use a technological information in the patent documents. In: II Intellectual Property and Technology Commercialization Meeting. Brazil.

CANAS, A.I., Camarero, S. (2010). Laccases and their natural mediators: biotechnological tools for sustainable ecofriendly process. Biotechnology Advances, 28(6), 694-705.

CARVALHO, W. et al. (2009). A vision of wood structure, composition and biodegradation. Química Nova, 32(8), 2191-2195.

IOGEN (20II). http://www.iogen.ca/bio_products/pulp_ paper/index.html [Accessed May 02, 201I].

JOSHI, C. and Khare, S.K. (20II). Utilization of deoiled Jatropha curcas seed cake for production of xylanase from thermophilic Scytalidium termophilum. Bioresource Technology, I02(2), I722-1726.

KAUR, A., and Mahajan, R. (20II). A novel and cost effective methodology for quantitative screening of alkalothermophilic cellulase free xylano-pectinolytic microorganisms using agricultural wastes. Journal of Industrial Microbiology \& Biotechnology, 27(2), 459-463.

KENERALY, W.R., and Jeffries, T.W. (2003). Enzymes Processes for Pulp and Paper: A Review of Recent Developments. American Academic Society. 29p.

KHANDERPARKER, R. and Numan, M.T. (2008). Bifunctional xylanases and their potential use in biotechnology. Journal of Industrial Microbiology \& Biotechnology, 35(7), 635-644.

KIRK, T.K., and Jeffries, T.W. (1996). In Enzymes for pulp and paper processing. American Chemical Society. Atlanta. pl-14.

KUHAD, R.C., and Singh, A. (2007). Lignocellulose Biotechnology: Future prospects. I.K. International Publishing House. 400p.

LEISOLA, M. et al. (200I): Industrial Use of Enzymes, Eolss Publishers, Oxford. 
LINTON, K., et al. (2009). Industrial Biotechnology: Patenting and Innovation, http://ssrn.com/abstract=130904 [Accessed August 02, 2010].

MISHRA, M., and Thakur, I.S. (20II). Purification, characterization and mass spectroscopic analysis of thermoalkalotolerant $\beta-I, 4$ endoxylanase from Bacillus sp and its potential for dye decolorization. International Biodeterioration \& Biodegradation, 65(2), 30I-308.

MOREIRA, L.R.S., and Filho, E.X.F. (2008). An overview of mannan structure and mannan-degrading enzyme systems. Applied Microbiology and Biotechnology, 79(2), 165-178.

NAGAR, S. et al. (2010). Production and optimization of cellulase-free, alkali-stable xylanase by Bacillus pumilus SV-85S in submerged fermentation. Journal of Industrial Microbiology \& Technology, 37 (I), 7I-83.

NISSEN, A. M., et al. (1992). in Xylans and Xylanases (eds Visser, J., Beldman, G., Kuster-van Someren, M. A. and Voragen, A. G.). pp. 325-337.

NOAH (20II). Biotechnology in Pulp and Paper Industry Applications and Research. http://www.make-paper.com/ biotechnology-in-pulp-and-paper-industry-applicationsand-research/ [Accessed May 02, 20II].

NOVOZYMES (2010). Annual Report. http://www.novozymes.com/NR/rdonlyres/74F74D89-D993-40D9-9609 -1396D2IB986C/0/The Novozymes Report_2009.pdf [Accessed August 02, 2010].

PAICE, M. (2005). Enzyme application in pulp and paper manufacturing. In. Paprican proceedings, Lakehead University Symposium. Canada. pl-40.

QUINDE, A. (1994). Enzymes in the pulp and paper industry: a review.http://www.quindeconsulting.ca/documents/ enzymes.pdf [Accessed August 02, 2010].

SANCHEZ,S., and Demain, A.L.(20II). Enzymesand bioconversions of industrial, pharmaceutical, and biotechnological significance.OrganicProcessResearch\&Development, I5(I),224-230.

SANGHI, A. et al. (2009). Enhanced production of cellulase-free xylanases by alkalophilic Bacillus subtilis ash and its application in biobleaching of kraft pulp. BioResources, 4(3), II09-II29.
SARVESHNI, P. (2007). Improvement of thermostability of fungal xylanase using error-prone polymerase chain reaction (EpPCR). PhD thesis.Dept. of Biotechnology, Durban University of Technology. 92p.

SASHI, V. et al. (2009). Fungal xylanases: their application and future prospects. Asian Journal of Environmental Science, 4(2), 235-24I.

SENIOR, D. et al. (1999). Enzyme use can lower bleaching costs, aid ECF conversions. Pulp and Paper, 73 (7), 59-62.

SUKUMARAN, R. et al. (2005). Microbial cellulases production, applications and challenges. Journal of Scientific and Industrial Research 64, 832-844.

SUURNAKKI, A.T.M. et al. (1997). Adv. in Biochem. Engin., (57), 26I-287.

TOLAN, J.S. et. al. (1995). "Survey of Xylanase Enzyme Usage in Bleaching in Canada". Pulp and Paper Canada, 96(I2), 107-II0.

VANTAGE POINT® software, Version 5.0, 2007.http:// www.thevantagepoint.com/support/details/19/1.html [Accessed August, 2009].

VIIKARI, L. et al. (1986). Third International Conference in Biotechnology in Pulp and Paper Industry, Stockholm, Sweden, p66-69.

VIIKARI, L. et al. (1994). FEMS Microb. Rev., (I3), 335-350.

VIOTTI, E.B., and Macedo, M.M. (2003). Indicators of Science, Technology and Innovation in Brazil. Unicamp, Brazil. 616p.

VIOTTI, E.B. (200I). Fundamentals and Evolution of Science, Technology and Innovation Indicators. Parana Institute of Productivity and Quality in connection with the Foreign Ministery of Commerce, Development and Industry (MDI ). Brazil.

ZHANG, W. et al. (2010). Expression and characterization of the Dictyoglomus thermophilium Rt46B.I xylanase gene $(x y n B)$ in Bacillus subtilis. Applied Biochemistry and Biotechnology, 160(5), 1484-1495. 
J. Technol. Manag. Innov. 20I I,Volume 6, Issue 3 